\title{
Doğal Afetlere Yönelik Vergi Politikaları ve Türkiye Uygulamalarının İncelenmesi
}

\author{
Hilmi ÜNSAL ${ }^{*}$
}

$\ddot{0} \mathbf{z}$

Yaşanan doğal afetlerin tahribatının giderilmesi ve yeniden inşa faaliyetleri, büyük ölçüde kamu kesimi tarafından gerçekleştirilmektedir. Özellikle depremler gibi olağanüstü durumlarda kamu harcamaları arttığı için kamu finansman ihtiyacı da artmaktadır. Doğal afet dönemlerinde ortaya çıan kamu finansman ihtiyacı, kamu maliyesinin konusuna girmektedir. Bahse konu finansman ihtiyacının karşılanması için bir taraftan ülke genelinde herkesi etkileyen ek vergiler konulurken, bir taraftan da doğal afetten zarar gören mükelleflerin vergi ödevlerini azaltıcı politikalar uygulanmaktadır. Bu çalışmanın konusu doğal afetlerin finansmanına yönelik vergi politikalarının incelenmesidir. Bu bağlamda konuya ilişkin teorik açılamalar yapıldıktan sonra Türkiye'de yaşanan Marmara depremi ve Van depreminde uygulanan vergi politikalarına yer verilecektir.

Anahtar Kelimeler: Doğal Afetler, Deprem Vergileri, Olağanüstü Vergiler, Deprem Sigortası, Özel İletişim Vergisi

\section{Tax Policies for the Natural Disasters and Examination of the Application Turkey}

\begin{abstract}
Removal of devastation of experienced natural disasters and reconstruction activities are carried out largely by the public sector. Especially in emergency situations such as earthquakes public financing needs for increased public spending increases. Public financing needs arising from natural disasters period, enters the subject of public finances. For such financing needs to meet the across the country one side mposing additional taxes affect everyone, from one side to the natural disaster
\end{abstract}

DOI: http://dx.doi.org/10.17336/igusbd.42070

* Doç. Dr., Gazi Üniversitesi, İ̇BF Maliye Bölümü Öğretim Üyesi,

E-posta: unsal.hilmi@gmail.com 
Sayfa/Page | 2 İGÜSBD

mitigation policies of tax payers damaged assignments are implemented. The aim of the study is to examine the tax policy for the financing of natural disasters. In this context after the theoretical explanations on the matter Marmara and Van earthquakes in Turkey will be included on tax policies.

Keywords: Natural Disasters, Earthquake Taxes, Earthquake Insurance, Emergency Taxes, Special Communication Tax

\section{Giriș}

Olağanüstü durumlarda ortaya çıkan kamu hizmetlerinin sunumu ve finansmanı, teorik olarak hem geleneksel devletin hem de sosyal refah devletinin asli fonksiyonlarının başında gelmektedir. Olağanüstü durumlar içerisinde önemli bir yer tutan doğal afetler yaşanmadan önce veya yaşandıktan sonra kamu kesiminin yapması gereken bazı görevler vardır. $\mathrm{Bu}$ görevlerden birisi doğal afetlere yönelik vergi politikalarıdır.

Doğal afetlere yönelik vergi politikaları yaşanan somut bir doğal afetle ilgili olabildiği gibi muhtemel doğal afetlerin etkisini hafifletici biçimde de olabilir. Somut bir doğal afete yönelik vergi politikalarının birinci biçimi finansman ihtiyacının karşılanmasına yönelik olarak ülke genelinde herkesi etkileyen ek vergilerin konulmasıdır. İkinci biçimi ise doğal afetten zarar gören mükelleflerin vergi ödevlerini azaltıcı vergi politikalarıdır.

$\mathrm{Bu}$ çalışmanın konusu doğal afetlerin finansmanına yönelik vergi politikalarının incelenmesidir. Bu çerçevede öncelikle doğal afetlere yönelik vergi politikalarına ilişkin açıklamalar yapılacaktır. Ardından yakın geçmişte Türkiye'de yaşanan Marmara depremi ve Van depreminde uygulanan vergi politikalarına yer verilecektir. Çalışma, değerlendirme ve öneriler kısmıyla tamamlanacaktır.

\section{A.MALIYY TEORISİ PERSPEKTIFINDEN DOĞAL AFETLER ve VERGİ POLITIKALARI}

Maliye teorisinin ana iştigal alanı mali olayların analizidir. Mali olaylar kamu harcamaları ve kamu gelirleri temelinde şekillenmektedir. Yaşanan olağanüstü durumların sonucunda kamu harcamaları ve kamu gelirleri hem miktar olarak artarken bileşim itibariyle değişmektedir. Maliye literatüründe savaş ve sosyal karışıklıklar gibi olağanüstü olayların kamu maliyesine etkisi 
sıçrama tezi ile açıklanmaktadır. Sıçrama tezi 1961 yılında A.T. Peacock ve J. Wiseman tarafından yazılan "Birleşik Krallık'ta Kamu Harcamalarının Artışı" adlı eserle ortaya atılmıştır1. Bu iki yazara göre kamu harcamalarının artışı, savaş gibi olağanüstü nedenlerden kaynaklanmaktadır. Burada her ne kadar açıcça doğal afetlerden bahsedilmese de doğal afetler de bir olağanüstüm durumdur. Bu noktadan hareketle olağanüstü durumda uygulanacak vergi politikaları ile sıçrama tezi arsında bağlantı kurulabilir.

Sıçrama tezine göre olağanüstü durumlarda artan kamu harcamalarını finanse etmek için devlet vergileri de artırır. Artan vergiler, sırf olağanüstü duruma olan bakışlarından dolayı seçmenler tarafından da kabul görür². Dolayısıyla yaşanan deprem ve diğer doğal afetlerden dolayı ortaya çıkan mali sorunların çözümünde hükümetler birincil kaynak olarak ek vergilere başvurmaktadırlar. Başlangıçta yaşanan doğal afetten kaynaklanan tahribatın giderilmesi için ihtiyaç duyulan finansmanı sağlamak amacıyla konulan bu vergiler, genellikle olağanüstü dönem sona erdikten sonra yine uygulanmaya devam edilmektedir. Zira bu vergilere seçmenler alışmıştır ve vergiler önceki seviyesine inmez ${ }^{3}$. Aslında yaşanan doğal afetlerin finansmanı için siyasi otoritelerin mükelleflerin olağanüstü durumda sahip oldukları psikolojik durumdan da yararlanarak koymuş oldukları vergiler, toplumun vergi yükünün tepkisiz bir şekilde artırılmasına yol açmaktadır.

\section{B.DOĞAL AFETLERİN MALİ ETKILERİ}

\section{Doğal Afetin Bütçe Kısıtına Etkisi}

Yaşanan doğal afetler, büyüklüğüne ve türüne göre farklı düzeylerde sosyal, ekonomik ve mali etkilere neden olmaktadır. Mali etkiler, devletin bütçe kısıtı üzerinde ortaya çıkan etkilerdir. Bütçe kısıtı devletin veri bir kaynak miktarıyla sunulabilecek maksimum hizmet miktarı ile ilgili bir kavramdır. Bütçe kısıtı hükümetin uygulayacağı politikalar konusundaki hareket alanını kısıtlamaktadır. Zira ortaya çıkan her yeni kamusal ihtiyaç, yeni kaynak gerektirmektedir. Kamusal kaynakların temini ise zordur.

\footnotetext{
${ }^{1}$ Magnus Henrekson, "The Peacock-Wiseman Hypothesis", In N. Gemmel, ed., The Growth of the Public Sector, Theories and International Evidence, Cheltenham: Edward Elgar Publishing, 1993, s. 54.

${ }^{2}$ Fatih Savaşan, Piyasa Başarısızlı̆̆ından Devletin Başarısızlığına Kamu Ekonomisi, 5.bs., Dora Yayıncılık, Bursa 2015, s. 46.

${ }^{3}$ Savaşan, a.g.e., s. 47.
}

Sayfa/Page | 3 
Sayfa/Page | 4 İGÜSBD Cilt: 3 Sayı: 2 Ekim / October 2016

Yaşanan doğal afetler, bütçeden yapılan kaynak tahsislerinin yerinin de değiștirmesine yol açmaktadır. Doğal afetler, beslenme, barınma, sağlık, istihdam, tahrip olan fiziki mekânların yeniden inşası gibi olağanüstü ve ani ihtiyaçları ortaya çıkartmaktadır. Yaşanan büyük yıkım dönemlerinde, öncelikli alt yapı yatırımları için ayrılmış kaynaklar, doğal afetten kaynaklanan ani sorunların çözümüne aktarılmaktadır4.

Büyük depremler gibi doğal afetlerin yaşandığı zamanlarda, mevcut bütçe kaynakları yeterli olmamaktadır. Böyle zamanlarda parlamento ek bütçe yaparak yeni kaynak arayışlarına girmektedir. Örneğin 1999 yılında Marmara bölgesinde yaşanan depremin gerektirdiği mali kaynaklar, ek bütçe yapılarak finanse edilmiştir.

\section{Doğal Afetlerin Vergi Kapasitesine Etkisi}

Vergi kapasitesi, hükümetin vergilendirebileceği potansiyel kaynakların toplamıdır. Modern vergileme anlayışında vergilerin gelir, servet ve tüketim üzerinden alındığı düşünüldüğünde, gelir, servet ve tüketimdeki artışın vergi kapasitesini artıracağı söylenebilir. Tersi durumda ise vergi kapasitesinin azalması kaçınılmazdır. Yaşanan doğal afetler, bir yandan üretim faktörü ve birikmiş servetin kaybına yol açarken diğer taraftan harcanabilir geliri azalttı̆̆ için tüketimin azalmasına yol açarak vergi kapasiteni azaltmaktadır.

Doğal afetin yaşandığı bölgelerde yaşanan en önemli mali sorun, vergi kaynaklarının kaybıdır. Bu kayıp en başta can kaybının neden olduğu iş gücü kaybı ve buradan ortaya çıkan gelir vergisi kaybıdır. İkinci olarak afetin yaşandığı yerlerdeki işyerlerinin yıkılması, ticari ve mesleki faaliyetlerden elde edilen kazancı azalttığı için gelir ve kurumlar vergisi kaybı söz konusu olmaktadır. En önemlisi ise özellikle büyük depremlerim yaşandığı bölgelerdeki ticari hayatta canlılığın azalması sonucu ortaya çıkan KDV ve ÖTV gibi tüketim vergileri kaybıdır.

Öte yandan özellikle birinci derece deprem bölgesi olan yerlerde mevcut olan deprem riski buralarda yapılan yatırımları azaltmaktadır. Yatırımların azalması ise vergi kapasitesinin azalmasına yol açmaktadır. Bu bölgelerden

${ }^{4}$ J. David Cummins, Olivier Mahul, Catastrophe Risk Financing in Developing Countries, Principles For Public Intervention, The Worldbank, 2009, Washington D.C., s.1. 
diğer bölgelere doğru yaşanan göç ise iş gücü kaymasından dolayı doğal afet bölgelerindeki mükellef sayılarını azaltmaktadır.

\section{Doğal Afetlerin Sigorta Sistemine Etkisi}

Doğal afetlerden kaynaklanan kayıpların telafisinde, mali açıdan devletin tek başına yeterli olamaması, sigortacılık sektöründen yararlanmayı zorunlu kılmıştır. Nitekim Dünya Bankası, doğal afetlerden kaynaklanan finansal risklerin azaltılması noktasında piyasa temelli bir sistemi benimsemiş olup bunu kamu-özel sektör ortaklığı benzeri bir yapı olarak desteklemektedir ${ }^{5}$. Türkiye'nin 2000 yllında kurduğu Zorunlu Deprem Sigortası Fonu Dünya Bankası desteğiyle temellenmiş ve geliştirilmiş bir fonlama sistemidir. Bu model, piyasa mekanizması temelli bir yapıdır. Kişi ve kurumlar sahip oldukları konut, taşıt, işyeri gibi mülklerini deprem ve diğer doğal afetlere karşı belli bir bedel karşılığında sigortalatmaktadırlar. Doğal afetten dolayı kayıplar oluştuğu zaman da bu kayıplar sigorta şirketlerince tazmin edilmektedir.

Yaşanan büyük boyutlu doğal afetlerde afetlerin mali yükü önemli ölçüde sigorta şirketleri üzerine binmektedir6. Bu durumda doğal afetlerin finansal risklerinin azaltılmasında sigorta yapanlar ile sigorta yaptıranlara yönelik uygulanan vergi politikaları önem arz etmektedir. Sektöre yönelik vergi politikaları, sigortacılık sektörünün doğal afetlerden dolayı göreceği zararı hafifletici bir yapıda dizayn edilmelidir. Örneğin sigorta şirketlerinin topladıkları fonlara karşılık, yüklendikleri riskle uyumlu bir vergi erteleme müessesesinin hayata geçirilmesi yerinde olabilir.

Öte yandan sigorta şirketlerinin ödemiş oldukları kurumlar vergisinin yüksekliği, dolaylı olarak deprem sigortası primlerinin yükselmesine neden olmaktadır7. Sigorta primlerindeki yükselme, doğal afetlere karşı sigorta yaptırma eğilimini azaltacaktır.

\footnotetext{
${ }^{5}$ Cummins ve Mahul, a.g.e., s. 3.

${ }^{6}$ Kay A. Cleary and Judy Pool Boutchee, "Reserving for Catastrophes", https://www.casact.org/pubs/forum/02fforum/02ff025.pdf, Erişim, 25.06.2016, s.28. ${ }^{7}$ Scott Harrington, Greg Niehaus, On the Tax Costs of Equity Finance: The Strange Case of Catastrophe Insurance, January, 2000, http://www.aria.org/rts/ proceedings/2000/taxcosts.pdf, Erişim, 24.06.2016, s. 1.
} 


\section{C.DOĞAL AFETLERE YÖNELİK VERGİ POLİTIKALARI}

Doğal afetlere yönelik politikaları; doğal afet yaşanmadan uygulanan vergi politikaları ve doğal afet yaşandıktan sonra uygulanan vergi politikaları biçiminde ikiye ayrılarak incelenebilir.

Sayfa/Page | 6 İGÜSBD Cilt: 3 Sayı: 2 Ekim / October 2016

\section{Politikaları \\ 1. Doğal Afet Yaşanmasına Bağlı Olmadan Uygulanan Vergi}

Doğal afetler yaşanmasına bağlı olmadan uygulanan vergi politikaları, kişileri doğal afete karşı koruma amacı taşıyan sigorta yaptırmaya yönelik teşviklerden oluşmaktadır. Zira sigorta sistemi doğal afetlerin tahribatının yeniden inşası sürecinde özel sektör tarafından finansman sağlayan bir yapıdır. Bu bağlamda gelir ve kurumlar vergisi mükelleflerin yaptırdıkları sigortalar veya ayırdıkları sigorta karșılıklarının belli bir kısmı vergi matrahından indirilebilmektedir. Böylece deprem, sel, yangın ve diğer doğal afetlere karşı özel sigortacılık teşvik edilmiş olmaktadır.

$\mathrm{Bu}$ politikalar, sigorta yaptıranlar açısından bir vergi avantajı biçiminde uygulanabilir. Şöyle ki yaptırılan doğal afet sigortaları nedeniyle ödenen primler ve katlanılan diğer giderlerin gelir ve kurumlar vergisi mükellefleri açısından giderleştirilme imkânı sağlanabilir.

Sigorta şirketleri açısından ise öncelikle yaptıkları sigorta miktarına göre ayırdıkları karşılıklar beyannameden düşülebilmektedir. Böylece bu şirketler için vergi matrahı bir miktar azaltılmış olmaktadır. Ayrıca özellikle doğal afetin yașandığı dönemlerde sigorta șirketlerinin mali yükünün artması kaçınılmaz olmaktadır. Böyle zamanlarda sigorta șirketleri için vergilerin ertelenmesi finansman açısından kolaylık sağlayabilir.

\section{Doğal Afet Yaşandıktan Sonra Uygulanan Vergi Politikaları}

Doğal afet yaşandıktan sonra uygulanan vergi politikaları; doğal afetin finansmanı için alınan ek vergiler ve mükelleflerin vergi yük ve ödevlerini hafifletici politikalar şeklinde ikiye ayrılarak incelenebilir.

\subsection{Doğal Afetin Finansmanı İçin Alınan Ek Vergiler}

Doğal afetlerden kaynaklanan fiziki, ekonomik ve sosyal tahribatın giderilmesi büyük finansman ihtiyacına neden olmaktadır. Söz konusu 
finansman ihtiyacı, bağışlar ve borçlanmayla belli ölçülerde karşılansa da yeterli olmamaktadır. Bu durumda mecburen ya mevcut veriler artırılmakta ya da vergi vb. mali yükümlülüklere başvurulmaktadır.

Doğal afet dönemlerinde devletin egemenlik gücünü kullanarak sağlayabileceği en kolay gelir vergilerdir. Zira olağanüstü zamanlarda toplumsal hassasiyetin artması, seçmenlerin siyasi iktidara karşı daha toleranslı davranmalarına neden olmaktadır. Seçmenler vergi yükleri artsa da bu yük artışına ciddi tepkiler vermemektedir.

Olağanüstü vergiler, verginin belirlilik, uygunluk ve ödeme gücü ilkeleriyle çelişebilmektedir. Nitekim 1999 yılında yaşanan depremin finansmanı için alınan ek vergiler, genellik, eşitlik, adalet ve belirlilik ilkeleriyle çelişmiştir8. $\mathrm{Bu}$ sebeple genellikle sınırlı bir süreyle uygulanmaktadır. Ancak deprem gibi olağanüstü durumda konulan bazı vergilerin sürekli vergi haline dönüştürüldüğü de bir gerçektir.

\subsection{Mükelleflerin Vergi Yükünü ve Ödevlerini Hafifletici Politikalar}

Doğal afetin yaşandığı bölgelerdeki vergi mükellefleri doğal afetten çeşitli düzeylerde etkilenmektedir. $\mathrm{Bu}$ etkilerin hafifletilmesi için mükelleflerin vergi yüklerini hafifletici bazı avantajlar sağlanabildiği gibi vergi ödevlerinde de kolaylıklar sağlanmaktadır.

Mükelleflerin vergi yüklerini hafifletici tedbirler; tahakkuk etmiş bazı vergilerin terkin edilerek tahsilinden vazgeçilmesi, o sene içerisinde alınan bazı vergilerin iade edilmesi biçiminde olabilir. Benzer şekilde vergi yükünü dolaylı olarak hafifletmek için firmaların doğal afetten zarar gören mallarının doğrudan giderleştirilmesi, yüklenilen KDV'lerinin indirime konu edilmesi ve hızlandırılmış amortisman uygulamaları yapılabilir.

Vergi ödevlerini kolaylaştırıcı tedbirler olarak; vergi ödemelerinde erteleme(tecil) ve mücbir sebep ilanına başvurulmaktadır. $\mathrm{Bu}$ iki uygulamadan birincisinde doğal afetten zarar gören mükellefler için bir finansal rahatlama saklanırken ikincisinde şekli ödevlerin yapılması konusunda mükelleflerin yükü hafifletilmektedir.

\footnotetext{
8 Mehmet Yüce, Vergileme İlkeleri ve Ekonomik Konjonktür Açısından Deprem Vergilerinin Genel Bir Değerlendirilmesi, http://www.mevzuatdergisi.com/1999/ 09a/03.htm, Mevzuat Dergisi, Yıl:2, Sayı: 21, Eylül 1999, s.1, Erişim, 07.05.2016.
}

Sayfa/Page | 7 


\section{D.TÜRKIYE'DE DOĞAL AFETLERE YÖNELİK VERGİ POLİTIKALARI}

Türkiye'de esas itibariyle fiilen yaşanan bir doğal afet nedeniyle,

Sayfa/Page | 8 İGÜSBD Cilt: 3 Sayı: 2 Ekim / October 2016 yaşanan doğal afete özgü vergi politikaları uygulandığı gözlemlenmektedir. Ancak vergi mevzuatı incelendiğinde, doğal afetlerin mükellefler üzerinde oluşturabileceği etkileri doğrudan veya dolaylı olarak azaltıcı bazı düzenlemelere yer verildiği gözlemlenmektedir. $\mathrm{Bu}$ nedenle öncelikle mevzuatta doğal afetlere yönelik vergisel düzenlemeler kısaca incelenecektir. Ardından yaşanan doğal afetler için uygulanan vergi politikaları incelenecektir.

\section{Vergi Mevzuatında Doğal Afetlere Yönelik Vergisel Düzenlemeler}

Türkiye'de Vergi Usul Kanunu'nda Gelir Vergisi Kanunu'nda ve Kurumlar Vergisi Kanunu'nda doğal afetlerin mükellefler üzerinde ortaya çıkarttığı etkileri azaltmaya yönelik vergi düzenlemeleri yapılmıştır.

Vergi Usul Kanunu'nda yer alan düzenlemeler;

- Mücbir sebep müessesesi(VUK m.13),

— Terkin müessesesi (VUK m.115),

— Fevkalade amortisman(VUK m.317) müessesesidir.

Mücbir sebep halinde mükellefin ödevlerinde erteleme imkânı sağlanmasının yanında vergi denetimi açısından da bazı avantajlar sağlanmaktadır. Doğal afet nedeniyle mücbir sebep ilan edilen yerlerde mükellefin beyanname verme süreleri uzadı̆̆ı için tahakkuk süreleri uzamaktadır. Benzer şekilde verginin ödeme süreleri de uzamaktadır.

Terkin müessesesi, yaşanan doğal afetler nedeniyle toplam mal varlığının en az üçte birini kaybeden mükelleflerin tahakkuk eden vergi ve cezaları, doğal afetten kaybettikleri mal varlıkları ile orantılı olarak terkin edilmektedir.

Fevkalade amortisman uygulaması; doğal afet nedeniyle amortismana tabi iktisadi kıymetlerin kaybedilmesi durumunda, bu iktisadi kıymetlerin bir defada amortisman ayrılarak giderleştirilmesini sağlamaktadır. Böylece vergi matrahı, indirilen gider kadar azalmış olacaktır.

Gelir Vergisi Kanunu'nda yer alan düzenlemeler; 
— DASK Sigortalarının Kira Gelirinden Düşülmesi; Meskenler için yaptırılan zorunlu deprem sigortaları, elde edilen kira gelirinden düşülebilmektedir.

— Doğal Afetler İçin Yapılan Bağışların Beyannameden Düşülmesi; GVK m.89 gereğince "Başbakanlıkça veya Bakanlar Kurulunca başlatılan yardım kampanyalarına makbuz karşılığı yapılan ayni ve nakdî bağışların tamamı" beyannameden düşülebilmektedir. Bu çerçevede doğal afetler için yapılan bağışlar da beyannameden düşülebilmektedir.

Kurumlar Vergisi Kanunu'nda yer ala düzenlemeler;

- Sigorta Şirketlerinin Ayırdıkları Karşılıklar(KVK m.8); Sigorta şirketlerinin ayırdıkları muallak hasar ve tazminat karşılıkları, kazanılmamış prim karşılıkları ve dengeleme karşılıkları beyannameden düşülebilmektedir.

- Doğal Afetler İçin Yapılan Bağışlar(KVK m.9); Başbakanlıkça veya Bakanlar Kurulunca başlatılan yardım kampanyalarına makbuz karşılığ yapılan ayni ve nakdî bağışların tamamı kurum kazancından indirilebilmektedir. Bu çerçevede doğal afetlerin finansmanı için yapılan bağışlar, beyannameden düşülebilmektedir.

- Ayrıca deprem sigortası yaptıran kurumlar vergisi mükellefleri ödedikleri primleri kurumlar vergisi matrahından düşebilmektedirler.

\section{Marmara ve Van Depreminden Sonra Uygulanan Vergi Politikaları}

Türkiye'de deprem, sel baskını, fırtına ve yer kayması gibi doğal afetler farklı büyüklüklerde yaşanabilmektedir. Özellikle depremlerin sıklıkla yaşandığı gözlemlenmektedir. Yaşanan depremin neden olduğu sosyal, ekonomik ve çevresel yıkımın büyüklüğüne göre finansman ihtiyacı değişmektedir. Öte yandan yaşanan doğal afetler vergi mükelleflerini de olumsuz etkilemektedir. Bu yüzden doğal afetleri göz önünde bulundurarak vergi politikaların uygulanması kaçınılmaz hale gelmektedir. Türkiye'nin son 20 yılda yaşadığı iki önemli deprem; 1999 yılında yaşanan Marmara depremi ve 2011 yılında yaşanan Van depremidir. Türkiye'de yaşanan Doğal afetler ve vergi politikaları bu iki deprem özelinde incelenecektir.

\subsection{Marmara Depreminden Sonra Uygulanan Vergi Politikaları}

17 Ağustos depremi Türkiye ekonomisinde neden olduğu sosyal maliyetlerin yanında büyük ekonomik kayıplara yol açmıştır. Ekonomik 
darboğazın yaşandığı dönemde ortaya çıkan bu depremin sonucunda, başta milli gelir azalmış, işsizlik artmış ve sermaye stoku azalarak ekonomik refah düşmüştür ${ }^{9}$. Aşağıdaki tablodan bu kayıplar açık bir şekilde gözlemlenmektedir.

Sayfa/Page | 10 İGÜSBD Cilt: 3 Sayı: 2 Ekim/ October 2016

Tablo 1: 17 Ağustos Depreminin Türkiye Ekonomisine Maliyetleri Maliyetler (Milyar Dolar)

\begin{tabular}{|c|c|c|c|}
\hline & DPT & $\begin{array}{l}\text { Dünya } \\
\text { Bankası }\end{array}$ & TUSİAD \\
\hline Doğrudan Maliyetler & 10,0 & $6,6-10,6$ & $3,1-6,5$ \\
\hline — İskân & 4,0 & $3,5-5$ & $1,1-3$ \\
\hline — İșletme & 4,5 & $2,5-4,5$ & $1,1-2,6$ \\
\hline - Altyapı & 1,5 & $0,5-1$ & 0,9 \\
\hline Dolaylı Maliyetler & 2,8 & $2-2,5$ & $1,8-2,6$ \\
\hline - Katma Değer Kaybı & 2,0 & $2-2,5$ & $1,2-2$ \\
\hline $\begin{array}{l}\text { - Acil Kurtarma } \\
\text { Masrafları }\end{array}$ & 0,8 & 0,6 & \\
\hline Toplam Maliyet & 13,0 & $9-13$ & $5-9$ \\
\hline \multicolumn{4}{|l|}{ İkincil Maliyetler } \\
\hline - $\quad$ Defter Kaybı & 2,0 & 3 & \\
\hline — $\quad$ Mali Zararlar & 2 & 5,9 & $3,6-4,6$ \\
\hline — $\quad$ Bölgedeki İş Kaybı & & & $\begin{array}{l}\text { Yüzde } 20 \text { - yüzde } \\
50\end{array}$ \\
\hline
\end{tabular}

Kaynak: Türkiye Raporu (OECD)'den naklen “Türkiye'de Doğal Afetler Konulu Ülke Strateji Raporu", Ankara Temmuz 2004, JICA, Japonya Uluslararası İşbirliği Ajansı, TC İçişleri Bakanlığı, s. 26.

Tablo incelendiğinde maliyetlerin yoğun olarak alt yapıda ortaya çıkan kayıplar olduğu anlaşılmaktadır. Alt yapıda ortaya çıkan kayıpların mali sisteme yansıması, vergi tabanının daralması biçimde ortaya çıkmaktadır. Dolaylı maliyetler içerisinde yer alan katma değer kayıpları ise üretken kapasitenin kaybı anlamına gelmektedir. Doğrudan maliyetler arasında yer alan işletme maliyetleri, kurumlar vergisi mükellefi ve katma değer vergisi

${ }^{9}$ Faruk Selçuk, Erinç Yeldan, “On The Macroeconomic Impact of the August, 1999 Earthquake in Turkey: A First Assessment”, Economic Research Forum (ERF), Working Paper, 2001, s. 488. 
mükelleflerinin kaybı anlamına gelmektedir. ikincil maliyetler arasında yer alan iş kayıpları ise $\% 20-\% 50$ arasında oldukça yüksek bir düzeydedir. Bu kayıplar gelir vergisi mükelleflerinin önemli bir kısmının mükellefiyetinin sona erdiğini göstermektedir. Bütün bu kayıplar bir yandan kamu finansman gereksinimi artırarak bir yandan da vergilendirilebilir kaynakları azaltarak bütçe kısıtını zorlaştırmaktadır.

\subsubsection{Konulan Ek Vergiler}

Depremin neden olduğu kaynak gereksinimini gidermek için başvurulan ilk yol yapılan olağanüstü bütçe çerçevesinde ek vergilerin konulması olmuştur. Bu bağlamda 26 Kasım 1999 tarihinde Deprem Vergileri Kanunu çıkartılmıştır10. Bu kanunla deprem vergileri adı altında bazı gelir ve servet unsurları üzerine vergi konulmuştur. Bu vergiler;

- Gelir unsurları üzerine konulan vergiler

- Servet unsurları üzerine konulan vergiler

— Harcama unsurları üzerine konulan vergiler olarak sınıflandırılabilir.

Gelir Unsurları Üzerine Konulan Vergiler: 1998 yılında beyan edilen gelir ve kurumlar vergisi matrahı üzerinden yüzde beş oranında ek gelir ve kurumlar vergisi alınmıştır. Kocaeli, Sakarya, Yalova ve Bolu illerinin merkez ve ilçelerinde gelir ve kurumlar vergisi mükellefiyeti bulunanlar ile depremde yakınlarını kaybedenler vergiden muaf kılınmışlardır.

Servet Unsurları Üzerine Konulan Vergiler: Servet unsuru olarak motorlu taşıtlar ve emlak üzerinden ikinci bir defa vergi alınmıştır. Ek emlak vergisi, 1999 yılı matrahı üzerinden alınırken Ek Motorlu Taşıtlar Vergisi 1999 yılı için tahakkuk ettirilen motorlu taşıtlar vergisi tutarı kadar alınmıştır. $\mathrm{Bu}$ iki vergi ile ilgili olarak da depremden zarar görenlere muafiyetler tanınmıştır. Depremde hayatını kaybedenlerin mirasçıları için Veraset Ve İntikal Vergisi istisnası sağlanmıştır.

Harcama ve İşlemler Üzerine Konulan Vergiler: 31.12.2003 tarihine kadar uygulanmak üzere deprem vergisi olarak Özel İletişim Vergisi ve Özel İşlem Vergisi öngörülmüştür.

${ }^{10}$ Kanun No: 4481, Kabul Tarihi: 26 Kasım 1999, Resmi Gazete ile Neşir ve İlânı: 26 Kasım 1999 - Sayı: 23888 (1. Mükerrer). 
Sayfa/Page | 12 İGÜSBD Cilt: 3 Sayı: 2 Ekim / October 2016

Özel İletişim Vergisi, cep telefonu işletmecilerinin sunduğu tesis, devir, nakil ve haberleșme hizmetleri üzerinden \%25 oranında alınmıştır. Bu vergi, uygulama süresi bitince geçici vergi olmaktan çıkartılmış ve sürekli vergi haline getirilmiștir. Kapsamı da genişletilmiștir. Verginin kanuni mükellefi bahse konu hizmetleri sunan mükellefler iken fiili yükleniciler bu hizmetlerden yararlananlardır.

Özel İşlem Vergisi, iki ayrı konu üzerinden alınmıştır. Bunlardan birisi eğitime katkı payı alınan işlemler ve kâğıtlar için ödenen eğitime katkı payı tutarı kadar ayrıca özel işlem vergisi alınmıştır. Diğeri ise vadeli mevduat ve vadeli döviz tevdiat hesabı ile özel finans kurumlarınca açllan katılma hesabı sahiplerinden, her vade sonunda, her bir hesap için bankalar ve özel finans kurumlarınca özel işlem vergisi alınmıştır.

\subsubsection{Depremin Vergi Tahsilatına Etkisi}

1999 depreminin finansmanı için sağlanan vergi hasılatı, ek gelir ve servet vergileri itibariyle aşağıdaki gibidir.

Tablo 2: Marmara Depreminden Sonra Konulan Ek Gelir Ve Servet Vergilerinin Dağılımı

\begin{tabular}{|c|c|c|}
\hline & 1999 & 2000 \\
\hline Toplam Vergi Gelirleri & 17.188 .408 & 30.869 .214 \\
\hline Toplam Ek Vergileri & 93.788 & 2.006 .740 \\
\hline - $E k G V$ & 21.571 & 96.527 \\
\hline$-\quad E k K V$ & 30.324 & 119.271 \\
\hline - EkMTV & 41.886 & 68.514 \\
\hline - Ek Faiz V & 5 & 1.657 .227 \\
\hline - EkEmlakV & 2 & 65.201 \\
\hline $\begin{array}{lllll}\text { Ek } & \text { Vergileri } & \text { Toplam } & \text { Vergi } & \text { Gelirleri } \\
\text { Íçindeki Payl } & & & \\
\end{array}$ & 0,5 & 6,5 \\
\hline
\end{tabular}

Kaynak: http://www.gib.gov.tr/sites/default/files/fileadmin/user upload/VI/GBG/Tablo 54.xls.htm

2000 yılı itibariyle konulan ek dolaysız vergilerin vergi gelirleri içindeki payı \%6,5 civarında gerçekleşmiştir. Bu orana Tablo 3'te belirtilen 2000 yılı için \%3,5'lik harcama vergileri de eklendiğinde deprem vergilerinin toplam vergi gelirlerinin \%10'u civarına ulaştığı anlaşılmaktadır. Bu oran, depremin 
finansmanında önemli ölçüde vergi gelirlerinden yararlanıldığını göstermektedir.

Grafik 1, ek vergiler içerisinde faiz üzerinden alınan vergilerin \%82,5 gibi oldukça yüksek seviyede olduğunu göstermektedir.

Sayfa/Page | 13

İGÜSBD

Cilt: 3 Sayı: 2

Ekim /

October 2016

Kaynak: http://www.gib.gov.tr/sites/default/files/fileadmin/user upload/VI/GBG/ Tablo 54.xls.htm

Grafikte de görüldüğü gibi gerçek kişilerin elde ettiği faiz gelirlerinden vergi alınarak depremin finansmanında kullanılması verginin sosyal amacına uygun olmuştur. Zira milli gelirin, faiz geliri elde edenlerden depremden zarar görenlere doğru aktarılmasını sağlayarak gelir dağılımının düzenlenmesine katkı sağlamıștır. Deprem dolayısıyla konulan harcama ve işlemler üzerinden alınan vergilerden sağlanan hasılata ilişkin bilgiler ise aşağıdaki tablodaki gibidir.

Tablo 3: 1999 Depreminden Sonra Konulan Harcama Vergilerinden Sağlanan Hasılat

\begin{tabular}{|l|l|l|l|}
\hline & $\mathbf{1 9 9 9}$ & $\mathbf{2 0 0 0}$ & $\mathbf{2 0 0 1}$ \\
\hline Özel İletişim Vergisi & 5 & 618000 & 592.072 \\
\hline Özel Íşlem Vergisi & 7.964 & 400000 & 320.280 \\
\hline 4705 S K G Tahsil Ed. Özel İşlem V. & & & 23.751 \\
\hline Vergi Gelirleri Içcindeki Pay & 0,04 & 3,30 & 1,57 \\
\hline
\end{tabular}

Kaynak: http://www.gib.gov.tr/sites/default/files/fileadmin/user upload/VI/GBG/ Tablo 54.xls.htm 
Veriler incelendiğinde 1999 yılında sağlanan hasılatın doğal olarak oldukça düşük olduğu gözlemlenmektedir. Ancak 2000-2001 yıllarında özel iletişim ve özel işlem vergilerinden sağlanan hasılat ise sırayla \%3,30 ve \%1,5 civarında gerçekleşmiştir.

Sayfa/Page | 14 İGÜSBD Cilt: 3 Sayı: 2 Ekim / October 2016

Depremin yaşandığı Marmara bölgesindeki illerde zarar gören bir diğer unsur, vergi kaynaklarında ortaya çıkan kayıptır. Bir önceki yıla göre tahsilattaki değişim, depremin vergi hasılatına etkisini görmek açısından bir karinedir.

Tablo 4: 1999-2000 Yıllarında Deprem Bölgesinde Vergi Tahakkuk ve Tahsilatlarında Ortaya Çıkan Değişim

\begin{tabular}{|l|l|l|}
\hline & $\mathbf{1 9 9 9}$ & $\mathbf{2 0 0 0}$ \\
\hline & Tahsilat & Tahsilat \\
\hline Bolu & 31.059 & 16.156 \\
\hline Kocaeli & 2.182 .343 & 3.763 .332 \\
\hline Sakarya & 34.376 & 41.222 \\
\hline Yalova & 16.153 & 29.942 \\
\hline Düzce & - & 9.903 \\
\hline
\end{tabular}

Kaynak: Gelirler Genel Müdürlüğü 1999 ve 2000 Yllı Faaliyet Raporları, http://www.gib.gov.tr/sites/default/files/fileadmin/faaliyetraporlari/1999/istatistikler .pdf ve http://www.gib.gov.tr/kurumsal/stratejik-yonetim/faaliyet-raporlari/gelirlergenel-mudurlugunun-2000-yilina-ait-faaliyet,

Tablo incelendiğinde depremin yaşandığı illerden sadece Bolu ilinde tahsilat düşerken diğer illerde artış söz konusudur. Ancak tahakkuk-tahsilat oranlarına bakıldığında durum değişmektedir. Tablo 5 tahakkuk-tahsilat oranlarını yansıtmaktadır. 
Tablo 5: 1999-2000 Yıllarında Deprem Bölgesinde Vergi Tahsilatın Tahakkuka Oranının ve Toplam Vergi Gelirleri İçindeki Payın Gelişimi

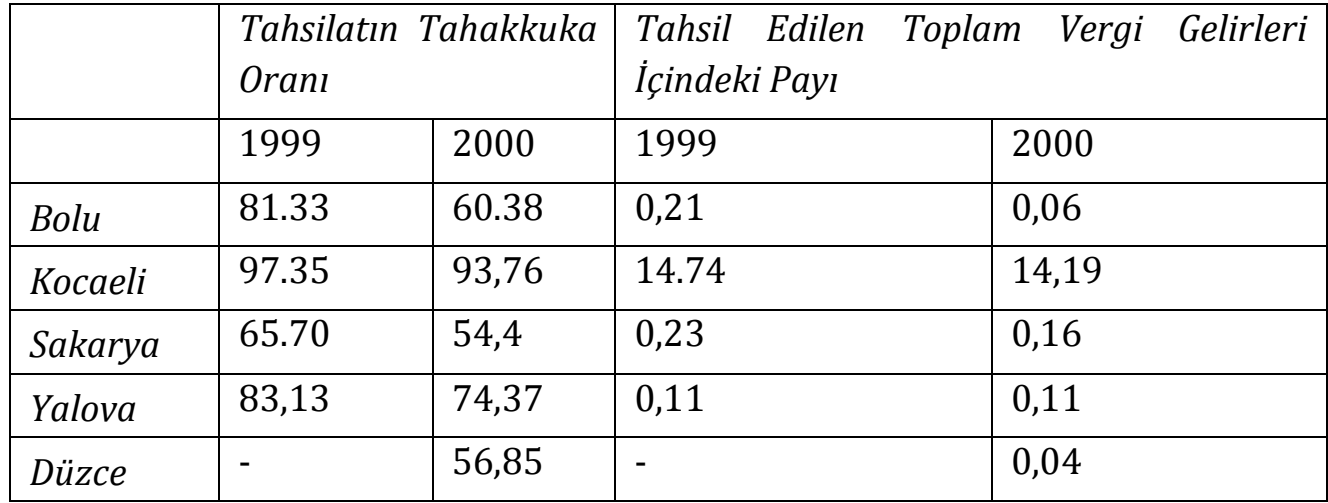

Kaynak: Gelirler Genel Müdürlüğü 1999 ve 2000 Yll Faaliyet Raporları, http://www.gib.gov.tr/sites/default/files/fileadmin/faaliyetraporlari/1999/istatistikler .pdf ve http://www.gib.gov.tr/kurumsal/stratejik-yonetim/faaliyet-raporlari/gelirlergenel-mudurlugunun-2000-yilina-ait-faaliyet

Tahsilat-Tahakkuk oranları, tahakkuk eden vergilerin fiilen ne kadarının tahsil edildiğini göstermektedir. Tahakkuk eden verginin hemen hemen tamamının tahsili, vergi idaresinin gayreti ve mükelleflerin ödeme imkânlarına bağlıdır. Depremin yaşandığı illerde 1999'da 2000 yılına geçişte bütün illerde tahakkuk-tahsilat oranları düşmüștür. Bu durum mükelleflerin ödeme imkânlarının zorlaştığının bir göstergesidir. Toplam vergi hasılatı içindeki payı itibariyle bakıldığında ise Yalova ili hariç diğerlerinde nispi de olsa düşüş yaşanmıştır.

Bütün bu bilgiler birlikte değerlendirildiğinde Marmara bölgesinde yaşanan depremin kümülatif olarak vergi hasılatında önemli büyüklükte azalmaya yol açtığı söylenebilir.

\subsection{Van Depreminden Sonra Uygulanan Vergi Politikaları}

Van ilinde 23 Ekim 2011 tarihinde 7,2 ve 9 Kasım 2011 tarihinde 5,6 büyüklügünde iki deprem yaşanmıştır. Yaşanan depremin sonucunda toplamda 644 can kaybı yaşanmıș ve 147.622'si konut, 18.735'i işyeri ve 20.279 'u ahır olmak üzere toplamda 186.636 yapı hasar görmüştür11. 2011 'den 2012'ye geçişte işgücüne katılım oranı \%2,3 düşerken işsizlik oranı

${ }^{11}$ Müdahale İyileștirme ve Sosyoekonomik Açıdan Van Depremi, TC Başbakanlık Afet ve Acil Durum Yönetimi Başkanlığl, Ankara 2014, s. 21-23. 
\%15,2'ye düşmüştür12. Yaşanan yıkımın sonucunda göç yaşanmış ve il nüfusunda bir miktar azalma söz konusu olmuștur.

Yaşanan depremin yaralarının sarılması için merkezi bütçe başta olmak

Sayfa/Page | 16 İGÜSBD Cilt: 3 Sayl: 2 Ekim / October 2016 üzere çeşitli kamu kurumlarından, sivil toplum kuruluşlarından ve yurt dışından mali kaynaklar sağlanmıştır. Aşağıdaki grafikten bu kaynaklar görülebilmektedir.

\section{Grafik 2: Van Depremi Sonrasında Aktarılan Mali Kaynakların Dağılımı}

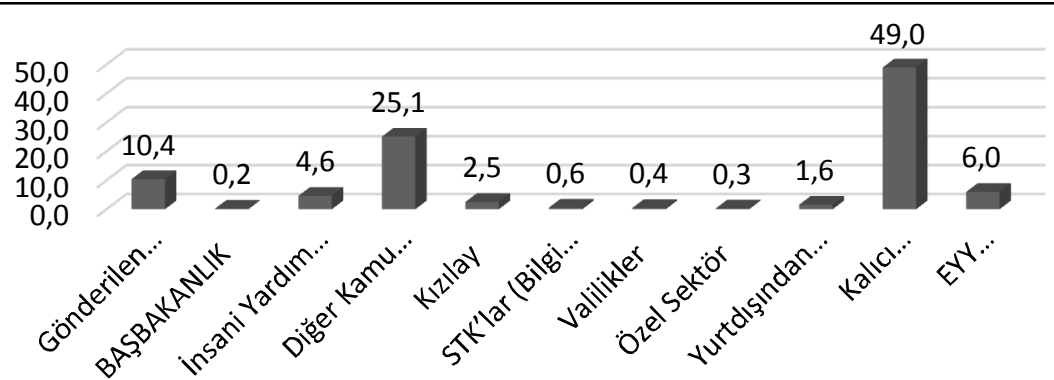

Kaynak: https://www.afad.gov.tr/tr/2388/Odenekler-Harcamalar-Kampanyalar

Grafik incelendiğinde deprem bölgesine gönderilen mali kaynakların \%49'unun konut yapımı için TOKİ tarafından sağlandığı gözlemlenmektedir. Ayrı bir kalem olarak dikkat çeken diğer ödenek ise acil yardım ödeneğidir. Genel olarak grafiğe bakıldığında sağlanan kaynakların hemen hemen \%90'ının kamu kesimince transfer edildiği anlaşılmaktadır.

Van depremindeki tahribatın giderilmesinde çok büyük kaynak gereksinimi olmadığı için yeni vergilerin konulması gündeme gelmemiştir. Dolayısıyla Van depremi sonrası toplumun vergi yükünü artırıcı politikalara başvurulmamıştır. Aksine depremin etkilediği alandaki mükelleflerin vergisel yükümlülüklerini yerine getirebilmeleri noktasında rahatlatıcı bazı politikalar uygulanmıștır. Bunlar; mücbir sebep ilanı, vergi ve cezalarda erteleme ve KDV avantajıdır.

\subsubsection{Mükelleflere Sağlanan Kolaylıklar}

Mücbir Sebep İlanı: Doğal afetler durumunda mükelleflerin vergi ödevlerini kolaylaştırmak adına öngörülmüş uygulamalardan birisi mücbir sebep halidir. Vergi Usul Kanunu'nun 15.maddesinde doğal afet durumların

12 Müdahale İyileştirme ve Sosyoekonomik Açıdan Van Depremi, agr., s. 72. 
Maliye Bakanlığı'nın mücbir sebep ilan edebileceği ve mücbir sebep süresince yerine getirilmeyecek ödevleri belirleme konusunda yetkilendirilmiștir. Maliye Bakanlığı bu yetkiyi kullanarak Van ilinde, Bitlis ili Adilcevaz ilçesinde ve Ağrı ili Patnos ilçesinde mücbir sebep ilan edilmiștiri³. İlan edilen mücbir sebeple mükelleflerin beyan ve ödeme zamanları ertelenmiştir. Mücbir sebep ilan edilerek mükelleflerin ödevlerinde rahatlama sağlanmıştır. Yoksa vergi ve cezalar terkin edilmemiştir.

Vergi ve Cezalarda Erteleme: Yaşanan deprem dolayısıyla, 23.10.2011 tarihinden önce tahakkuk eden ancak vadesi bu tarihten sonra gelen her türlü vergi, ceza ve gecikme faizinin ödeme süresi de ilerde belirlenecek bir tarihe kadar uzatılmıștır. Ayrıca ikmalen, re'sen veya idarece tarh edilen ve vadesi mücbir sebep ilan olunan tarihten sonrasına rastlayan her türlü vergi, ceza ve gecikme faizinin ödeme süresi ileride belirlenecek bir tarihe kadar uzatılmıştır. Vergi ve cezalardaki erteleme finansal kolaylık sağlayan bir düzenlemedir.

KDV'de Avantaj: Vergi Usul Kanunu'nun 30.maddesi hükmü gereği olarak deprem nedeniyle zayi olan mallardan dolayı yüklenilen KDV'nin indirim konusu yapılabileceği düzenlenmiştir. Van depremi nedeniyle zayi olan mallar, belgelendirilemeseler dahi mücbir sebep hükümlerinden de yararlanılarak takdir komisyonu kararıyla indirim konusu yapılabilmiştir.

\subsubsection{Van Depreminin Vergi Tahsilatına Etkisi}

Van ilinde yaşanan depremden dolayı il düzeyinde vergisel kayıplar da kaçınılmaz hale gelmiştir.

Tablo 6: Van Depreminin Vergi Tahsilatına Etkisi

\begin{tabular}{|l|l|l|l|l|l|}
\hline & Tahakkuk & Tahsilat & $\begin{array}{l}\text { Tahakkuk - } \\
\text { Tahsilat } \\
\text { Oranı }\end{array}$ & Tahsilat Artışı & $\begin{array}{l}\text { Tahsilat } \\
\text { Íçindeki Payı }\end{array}$ \\
\hline 2010 & 475.141 .846 & 369.661 .958 & 77,8 & 21,15 & 0,16 \\
\hline 2011 & 569.586 .931 & 425.034 .533 & 74,62 & 14,98 & 0,15 \\
\hline 2012 & 681.780 .567 & 429.962 .221 & 63,06 & 1,16 & 0,14 \\
\hline
\end{tabular}

Kaynak: http://www.gib.gov.tr/sites/default/files/fileadmin/user upload/VI/GBG/ Tablo 61.xls.htm

${ }^{13}$ Seri: B Sıra No: 7, Tahsilat Genel Tebliği, Resmi Gazete No: 28514 (4.Mükerrer), Resmi Gazete Tarihi: 31/12/2012. 
$\mathrm{Bu}$ bağlamda tahakkuk-tahsilat oranları \% 63'lere kadar düşerken toplam vergi hasılatı içindeki payı da \%0,16'dan \%0,14'lere kadar düşmüştür. En dramatik düşüş ise, bir önceki yıla göre vergi tahsilatındaki artıştadır. 2010 yılında vergi tahsilatındaki artış \%21,15 iken bu oran hızla düşmüş ve 2012

Sayfa/Page | 18 İGÜSBD Cilt: 3 Sayı: 2 Ekim / October 2016 yılında \%1,16'ya düşmüştür. Bütün bu bilgiler birleştirildiğinde Van depreminin sonucunda bu bölgede vergi kapasitesinin oldukça azaldığ gözlemlenmektedir. Zira işyeri kaybı, göç ve ölüm-sakatlık gibi nedenlerle işgücünde ortaya çıkan kayıplar bu yargıyı desteklemektedir.

\section{E.GENEL DEĞERLENDİRME ve ÖNERİLER}

Maliye biliminde savaş ve sosyal karışıklıklar gibi olağanüstü olayların kamu maliyesine etkisi sıçrama tezi ile açıklanmaktadır. Bu teze göre kamu harcamalarının artışı, savaş gibi olağanüstü nedenlerden kaynaklanmaktadır. Doğal afetler de bir olağanüstüm durum olduğu için bu durumlarda artan kamu harcamalarını finanse etmek için vergilerin de artırıldı̆̆ı bilinen bir gerçektir.

Doğal afetler, başta bütçe kısıtı olmak üzere, vergi kapasitesi, mükelleflerin vergi ödeyebilme imkânları, sigorta sistemi gibi birçok farklı konu üzerinde mali etkiler doğururlar. Söz konusu etkiler, doğal afetlere özgü vergi politikalarının geliştirilmesini zorunlu kılar. Bu politikaların bir boyutu doğal afetten zarar gören mükelleflerin vergisel yükümlülüklerinin azaltılması ile ilgili iken bir boyutu yeni vergilerin konulması ile ilgilidir. Ayrıca doğal afet yaşanmasına bağlı olmaksızın doğal afetlerle mücadele amacıyla vergi mevzuatında çeşitli düzenlemeler de yapılmaktadır.

Türkiye'de Marmara depremi sonrası konulan ek vergilerden 2000 yılı itibariyle vergi gelirlerinin \%10'u civarında bir tahsilat sağlanmıştır. Bu tutar toplumun ilgili dönem için vergi yükünde \%10'luk bir artış anlamına gelmektedir. Ancak depremin neden olduğu yıkımın finansmanı için bu vergiler önemlim katkı sağlamıştır. Deprem döneminde konulan bu vergilere toplum uyum göstermiştir, ancak 2001 yılından sonra özel iletişim vergisinin genişletilerek uygulanmasına devam edilmesi tepkilere neden olmuştur.

Hem Marmara depremi hem de Van depremi sonrasında mükelleflere sağlanan vergisel kolaylıklar, depremden etkilenen mükellefleri ödevlerini yapabilmeleri konusunda rahatlatmıştır. 
Vergi mevzuatında yer alan düzenlemelerden özellikle Vergi Usul Kanunu'nda yer alan mücbir sebep, terkin ve fevkalade amortisman uygulaması, mükelleflerin sıklıkla başvurdukları işlevsel düzenlemelerdir. Katma Değer Vergisi Kanunu'nda doğal afetler nedeniyle zayi olan malların KDV'sinin indirim konusu yapılabilmesi de uygulamada yararlanılan düzenlemelerdendir. Kurumlar Vergisi Kanunu'nda sigorta şirketlerinin giderleştirebildikleri karşılıklar, sigorta şirketlerinin doğal afetlere karşı mali güçlerini artırıcı bir düzenleme olarak işlev görmektedir.

Bahsedilen bu düzenlemeler, doğal afetlerle mücadelede yeterli olmamaktadır. Zira sadece doğal afet yaşanması durumunda uygulanan vergi politikaları vardır. Oysa konu daha geniş bir bakış açısıyla ele alınmalı ve afete hazır bir yapının oluşturulması hedeflenerek vergi politikası dizayn edilmelidir.

Doğal afetlerin finansmanı konusunda Türkiye'de yapılabilecek en önemli yenilik, krizlerle mücadele için öngörülen "mali alan" benzeri bir yapının kurulmasıdır. Oluşturulacak bu kaynak havuzuna özellikçe çevreye, sağlığa zararlı olan maddeler üzerine konulacak düşük miktarlı vergilerden kaynak aktarılmalıdır.

Gelir Vergisi Kanunu'nda depreme karşı yaptırılan zorunlu sigorta giderleri sadece ilgili gayrimenkulün kiraya verilmesi durumunda giderleştirilebilmektedir. Deprem sigortası giderleri, bu düzenlemenin dışında gelir vergisi mükelleflerinin beyannameden düşebilecekleri giderler arasında yer almamaktadır. Bu sebeple Doğal afetlere karşı sigorta yaptıran her gelir vergisi mükellefinin ödemiş olduğu sigorta giderlerinin vergi matrahından düşürülmesi imkânı sağlanmalıdır.

Nihayet sigorta şirketleri için doğal afetin yaşandığı dönemlerde mali açıdan rahatlık sağlayıcı vergi düzenlemeleri yapılmalıdır. Bu amaçla, oluşacak ödeme yüküne göre vergi ertelemesi müessesesi getirilebilir.

\section{Sonuç}

Türkiye'de doğal afetler sıklıkla yaşanmaktadır. Ancak tahribat noktasında en etkili olan doğal afet türü depremlerdir. Türkiye'de 1999 yılında yaşanan Marmara depremi ve 2011 yılında yaşanan Van depremi yakın geçmişte yaşanan dikkat çekici doğal afetlerdir. Her iki doğal afette de vergi politikalarının uygulandığı gözlemlenmektedir. Uygulanan vergi

Sayfa/Page | 19 
Sayfa/Page | 20 İGÜSBD Cilt: 3 Sayı: 2 Ekim / October 2016

politikalarının genel karakteristiği depremden etkilenen mükelleflerin yüklerini hafifletici politikalar olmalarıdır. Marmara depreminde, Van depreminden farklı olarak bazı gelir ve servet unsurları üzerine ek vergiler konulmuş ve özel iletişim vergisi ve özel işlem vergisi adları altında yeni vergiler ihdas edilmiştir.

$\mathrm{Bu}$ vergilerden özel iletişim vergisi sürekli vergi haline getirilmiştir. Geçici vergi iken sürekli vergi haline getirilen bu vergi Peacock-Wiseman tarafından ileri sürülen sıçrama tezini doğrulayan tipik bir örnek olmuştur. Sırf olağanüstü bir döneme dayanılarak konulan bu vergiye mükellefler alıştığı için tepki vermemişlerdir. Dolayısıyla toplum vergi yükünde zımni bir artış söz konusu olmuştur.

Genel olarak değerlendirildiğinde Türkiye'de doğal afet yaşandıktan sonra vergi politikalarının uygulandığı gözlemlenmektedir. Doğal afetin neden olabileceği tahribata önceden hazırlık amacı taşıyan bir politikanın olmadığı gerçek bir sorun olarak ortada durmaktadır. Deprem kuşağında yer alan bir ülke olduğu göz önünde bulundurularak, zaman kaybetmeksizin hem doğal afetlerin finansman ihtiyacını önemli ölçüde karşılayacak hem de doğal afetlerden doğacak zararların minimize edilmesini sağlayacak altyapı kurulumuna hizmet edecek bir vergi yapısının kurulması gerekmektedir.

\section{KAYNAKÇA}

CLEARY, Kay A. and Judy Pool BOUTCHEE, "Reserving for Catastrophes", https://www.casact.org/pubs/forum/02fforum/02ff025.pdf, Erişim, 25.06. 2016.

CUMMINS, J. David, Olivier MAHUL. Catastrophe Risk Financing in Developing Countries, Principles For Public Intervention, The Worldbank, Washington D.C., 2009.

Gelirler Genel Müdürlüğü 1999 Yılı Faaliyet Raporu, http://www.gib. gov.tr/sites/default/files/fileadmin/faaliyetraporlari/1999/istatistikler.pdf, Erişim, 05.07.2016

Gelirler Genel Müdürlüğü 2000 Yılı Faaliyet Raporu, http://www.gib. gov.tr/kurumsal/stratejik-yonetim/faaliyet-raporlari/gelirler -genelmudurlugunun-2000-yilina-ait-faaliyet Erişim, 05.07.2016

HARRINGTON, Scott, Greg NIEHAUS. On the Tax Costs of Equity Finance: The Strange Case of Catastrophe Insurance, January, 2000, http://www.aria.org/rts/proceedings/2000/taxcosts.pdf, Erişim, 24.06.2016. 
HENREKSON, Magnus, "The Peacock -Wiseman Hypothesis”, In N. Gemmel, ed., The Growth of the Public Sector, Theories and International Evidence, Cheltenham: Edward Elgar Publishing, 1993.

Müdahale İyileştirme ve Sosyoekonomik Açıdan Van Depremi, TC Başbakanlık Afet ve Acil Durum Yönetimi Başkanlığı, Ankara, 2014.

SAVAŞAN, Fatih, Piyasa Başarısızlığından Devletin Başarısızlığına

Kamu Ekonomisi, 5.Baskı, Dora Yayıncllık, Bursa, 2015.

SELÇUK, Faruk, Erinç YELDAN, "On The Macroeconomic Impact of the August, 1999 Earthquake in Turkey: A First Assessment”, Economic Research Forum (ERF), Working Paper, 2001.

Türkiye'de Doğal Afetler Konulu Ülke Strateji Raporu, Ankara Temmuz 2004, JICA, Japonya Uluslararası İşbirliği Ajansı, TC İçişleri Bakanlığı

YÜCE, Mehmet. Vergileme İlkeleri ve Ekonomik Konjonktür Açısından Deprem Vergilerinin Genel Bir Değerlendirilmesi, http://www.mevzuatdergisi.com/1999/09a/03.htm, Mevzuat Dergisi, Yll:2, Sayı: 21 Eylül 1999, Erişim, 07.05.2016.

\section{Summary}

Removal of devastation of experienced natural disasters and reconstruction activities are carried out largely by the public sector. Especially in emergency situations such as earthquakes public financing needs for increased public spending increases. Public financing needs arising from natural disasters period, enters the subject of public finances. For such financing needs to meet the across the country one side mposing additional taxes affect everyone, from one side to the natural disaster mitigation policies of tax payers damaged assignments are implemented. The aim of the study is to examine the tax policy for the financing of natural disasters. The subject of the study is to examine the tax policy for the financing of natural disasters.

In the public finance literature describes with splashing thesis the impact on public finances of extraordinary events such as war and social confusion. According to this thesis, increased public spending is due to exceptional reasons such as war. Although clearly pronounced way to natural disasters from natural disasters is an extraordinary events. According to the splashing thesis also the state increase of taxes to finance increased public spending in extraordinary events. 
Sayfa/Page | 22 İGÜSBD Cilt: 3 Sayı: 2 October Ekim /

Natural disasters, especially budget constraints, tax capacity, opportunities for taxpayers to pay taxes, they lead the financial effects on many different topics such as insurance system. These influences, natural disasters requires the development of specific tax policy. While dealing with a dimension reduction of the tax liabilities of taxpayers who suffer from natural disasters it is about the dimension of this set of new tax policy. In addition, various regulations in the tax legislation to scramble natural disasters regardless of natural disasters, is well maintained.

The natural disasters often occurred in Turkey but the damage from the earthquake are the most effective type of natural disaster. In this study, tax policies implemented were examined in the quake and the Van earthquake occurred in Turkey. Marmara earthquake on the basis of income and additional taxes imposed on elements of fortune and special communication tax and new tax names under a special transaction tax were established. The special communication tax from this tax has become sustained tax. Set out after the Marmara earthquakes additional tax revenue from the tax in the 2000 year is provided with a receiving of around 10\%. This amount refers to a $10 \%$ increase in the tax burden for the relevant period of the society. However, these taxes for financing the destruction caused by the earthquake has made a significant contribution. During the earthquake period showed society adapt to these taxes levied, but since 2001 has led to expanded response to continued implementation of special communication tax. Both Marmara earthquake as well as Van earthquake the facilities provided to taxpayers after tax, taxpayers affected by the earthquake have been reassured that they do their work.

In Turkey, regarding the natural disasters financing of the most important innovations that can be done prescribed to struggle the crisis "fiscal space" is the establishment of a like structure. This resource pool will be created on the property of the environment, it will be placed on low-volume substances that are harmful to health must be transferred tax sources.

In especially, located in Tax Procedure Law force majeure, cancelment, application of exceptional depreciation of the regulations in the tax legislation are functional arrangments they frequently refer to the taxpayer. Value Added Tax of natural disasters can be made subject to deduction of VAT due to loss goods which are among the arrangements used in practice. In Corporate Tax Law could expensing provisions of the insurance companies to increase the financial strength of insurance against natural disasters serve as a regulation. 
Doğal Afetlere Yönelik Vergi Politikaları ve Türkiye Uygulamalarının İncelenmesi

That the compulsory insurance costs against earthquake commissioned on Income Tax Law can be expensed when administered to only rent the property concerned. Earthquake insurance expenses out of this arrangement declaration colud fall expenses are not included in the of income tax payers. Therefore, insurance is paid by taxpayers of all income tax expense of insurance cover against natural disasters the oppurtunity should be tax deductible. 